\title{
MONEY SUPPLY AND INFLATION IN NIGERIA: THE MYTH OF THE MONETARIST THEORY OF INFLATION
}

\author{
Ibrahim Abdulhamid Danlami ${ }^{1+}$, Mohamad Helmi Bin Hidthiir ${ }^{2}$ and Sallahuddin Hassan ${ }^{3}$ \\ ${ }^{1}$ School of Continuing Education, Bayero University, Nigeria \\ ${ }^{2}$ School of Economics Finance and Banking, Universiti Utara Malaysia, \\ + Corresponding author: iadanlami.sce@buk.edu.ng
}

\begin{abstract}
The inability of Nigeria to make its inflation rate a single digit motivates this study. This paper aims to empirically investigate whether inflation is solely caused by the increase in money supply beyond what is required by the economy, as maintained by monetarists using Nigerian data. Autoregressive Distributed Lag Model (ARDL) was used as the tool of econometric analysis on Nigerian time series data for 48 years. The ARDL was chosen because unit root tests were conducted. The results show that variables are not integrated in the same order. Money supply increment is demonstrated to be inflationary only in the short-run. The existence of other factors that influence inflation in the country is also evident. While money supply has no significant influence on inflation, the GDP and the constant have a significant influence on inflation in the long-run. Therefore, justification is provided for the myth of monetarist theory of inflation, claiming that money supply increment is a sole source of inflation, especially in Nigeria. Even though the result of the Wald test shows that the coefficients of money supply combined have a significant effect on inflation in conformity with the monetarist theoretical arguments, such effects are limited to short-run only. The findings of the research are limited to Nigeria whose data are used, based on ARDL as the econometrics techniques applied, for a period of 48 years from 1970-2017. Generally speaking, explanations for theories regarding inflation, especially in developing nations, should not be taken for granted. The research empirically demonstrates that the monetarist theory of inflation is a myth and not reality by using Nigerian data. It also suggests that other theories should be empirically tested to check which one best explain the nature of inflation dynamics in a country to proffer a better solution to a high inflation rate problem.
\end{abstract}

Keywords. ARDL, Inflation, Monetarist, Myth of Monetarist, Nigeria. JEL Codes. E00, E31, E51

Received 15 April 19. Revised 29 March 20. Accepted 2 April 20.

\section{Introduction}

For several decades, increases in prices are perceived to be the consequence of increases in money supply (Danlami, 2019; Danlami, Hidthiir, \& Hassan, 2018). Such generalizations are made without exception and thorough empirical tests despite the fact that countries differ in the level of their economic growth, as well as how things operate. Developed economies differ greatly from developing economies in policymaking and economic performances. Developed economies enjoy the advantages that come with price stability, whereas developing economies suffer most from fluctuations in prices. The frequent changes in the general price level have been the major concern of many countries. The inability of many economies to reap the advantages of price stability resulting from high prices fluctuations pose a serious challenge to policymakers and researchers. Price stability ensures not only the provision but also the promotion of long-term economic growth. A high rate of inflation has been shown to have adverse effects on the economies of countries (Sek, Teo, \& Wong, 2015). 
Monetary regulators in various countries agree that sustainable price stability should be the key objective of monetary policy, taking into consideration unfavorable impacts of inflation on their respective economy. Thus, having sustainable price stability persists to be the central primary objective of monetary policy in most countries. The social importance given to normality and stability of price in the running and control of monetary policy lies in fostering (nurturing) sustainable economic growth and development and fortifying the legal tender of the country, consequent to improving the general welfare of the people (Audu \& Amaegberi, 2013; Bawa, Abdullahi, \& Ibrahim, 2016).

Shamsul-Alam and Kamath (1986) pointed out that the theoretical explanation of inflation in most developing economies could be grouped into two perspectives: the monetarist and structuralist points of view. To the monetarists, inflation anytime anywhere is caused by an increase in the money supply. This implies that only the growth rate of the money supply determines inflation. The existence of rigidities or constraints and a lack of freehand in the economies of developing countries are perceived to be the sources of inflation in such economies by the structuralists. The lack of freehand involves excessive government intervention, such as excessive exchange rate devaluation, minimum wage legislation, and other structural bottlenecks that result from the government intervention. Several theories highlight their perceptions about the causes of inflation - from an increase in costs of production to the existence of excess demand over supply and several other issues.

One of the major factors hindering the economic growth of developing economies is a high rate of inflation. Many researchers recommend the maintenance of a single-digit rate of inflation for economic growth stimulation of developing economies (Anwar \& Islam, 2011; Danlami, Hidthiir \& Hassan, 2018; Phiri, 2012; Risso \& Sanchez-Carrera, 2009). Nigeria, as a developing economy, has a history of a high rate of inflation, most times double-digit, above the recommended rate. Figure 1 shows Nigeria's rates of inflation for 46 years (almost five decades). In the first decade (1970 - 1979), only two years of a single-digit inflation rate were recorded. In the second and third decades (1980 - 1989 and 1990 -1999), four years of single digits inflation rates were recorded. Also, three years of single-digit inflation rate were recorded in the fourth decade of $2000-2009$ and last decade of 2010 - 2015. The average inflation rate for the 46 years is above 18 percent.

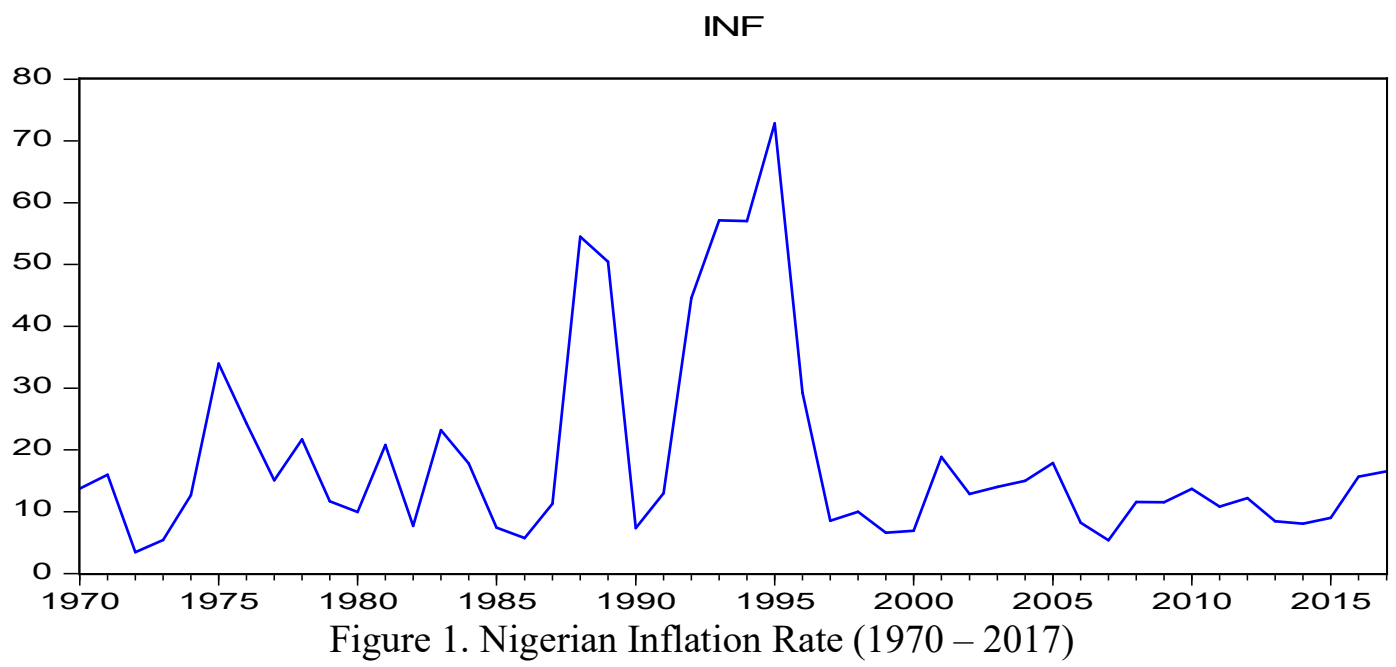

Source: World Development Indicator 2019 
The theoretical explanation for Nigeria's inflation rate changes will be opined to a specific perception of the theory. For instance, a monetarist would declare it as a consequence of altering the country's money supply. In contrast, Keynes and neo-Keynesian would attribute it to excessive aggregate demand from the civil, military, government or both. The structural rigidity theory would implicate the existence of constraints, rigidities, and bottleneck in the economy as the source of inflation in the economy.

This research aims at empirically analyzing the money supply and inflation to vindicate or otherwise the proposition of the monetarist theory on inflation in Nigeria. The model used in this paper is dictated by the level of integration of the variable (level of variables' stationery) as against the arbitrary model selection by some papers. The remaining sections of the paper consist of a literature review and theoretical framework. The methodology used in this study is highlighted in section three. Section four presents the results, while the conclusion formed the last section of the paper.

\section{Literature Review}

Studies that directly and empirically investigated the arguments of monetarists on inflation are limited. However, research has empirically considered the effect of the variables that reported results either in accord or against the theoretical arguments. Such variables include the effect of money supply and economic growth on inflation. Depending on the country or cluster of study and the methodology used, the results reported are entirely inconsistent, and their findings are inconclusive. Therefore, the results in one area or region cannot be generalized in another area or region. Asongu (2013) reported that money supply is empirically significant and positively influencing inflation using Vector Autoregressive (VAR) and Vector Error Correction Model (VECM) in 10 African countries. Mawajje and Lwanga (2016) reported a similar finding in the short run in Uganda. Also, using the same methodology, Simpasa et al. (2011) and Okhiria and Saliu (2008) reported a similar result in East Africa and Nigeria, respectively. Adu and Marbuah (2011) also reported a positive and significant influence of money supply on inflation in Ghana using Autoregressive Distributed Lag Model (ARDL), Dynamic Ordinary Least Squares (DOLS) and Fully Modified OLS (FMOLS).

Hossain and Islam (2013) applied Ordinary Least Square (OLS) on Bangladesh's data and maintained that significant inverse effect exists on inflation by money supply. In contrast, Nguyen (2014) employed the Generalized Method of Moment (GMM) and showed that money supply influences inflation negatively in Asian countries. On the other hand, Lim and Papi (1997) showed insignificant results of the relationship between money supply and inflation by using DOLS and VECM in the Turkish economy. Lim and Sek (2015) used ARDL in the short run of high inflation countries and a long run of low inflation countries.

Several studies report a positive influence of Gross Domestic Product (GDP) as a measure of economic growth on inflation. Aliyu and Englama (2009) reported that the response of inflation to GDP shocks is positive in Nigeria using the Impulse Response Function (IRF). While in Pakistan, Bashir et al. (2011) also reported similar findings using VECM. Omoto (2008) and Adelowokan (2012) used data from Nigeria and applied VECM and OLS, respectively. They showed a positive influence on inflation by GDP.

Furthermore, Adu and Marbuah (2011) found a significant inverse influence of GDP on inflation by using ARDL, FMOLS and DOLS in Ghana. Omotor (2008) showed the same result by using VECM, Granger Causality (GC), and Impulse Response Function (IRF) in Nigeria. Other studies also reported the same result, including Bashir et al. (2011), who used VECM in 
Pakistan and Bobai, Ubangida, and Umaru (2013), who used VECM in Nigeria. On the other hand, Risso and Sanchez-Carrera (2009) in Mexico reported an insignificant effect of GDP on inflation. Ojede (2015), who employed GMM in Nigeria, and Nguyen (2014), who used both Pool Mean Group (PMG) and GMM in Sub-Saharan Africa (SSA), found a similar result.

Some results of the empirical studies are consistent with theories while some are not. For instance, the monetarist theory of inflation maintains that the consequence of increasing money supply is inflation, and therefore, inflation anytime anywhere results as an increase in money supply. Keynes and the short-run analysis of a neo-Keynesian strand of thought believe that an increase in money supply at below full-employment level would only lead to a rise in the level of employment and output although prices would not be affected. It is only at the fullemployment level that increases in money supply will influence and increase the price level because there is no room for employment and output increment (Mordi et al., 2007).

\section{Theoretical Framework}

The variables analyzed in this study were selected based on the arguments of the monetarist theory of inflation. As highlighted earlier, the monetarists believe that inflation rises in response to increments of money supply beyond what is required by the economy. This is based on the assumption that money supply is solely used as a medium of exchange, and its effects and influences determine the prices of goods and services without affecting the rest of the economy (employment level, income level, and the level of output) (Jhingan, 2011).

\section{Methodology}

Unit root tests were conducted. The results reveal that the variables are not integrated in the same order. Some are stationary at level I(0) while some are stationary after being first differenced I(1). Accordingly, the best model to use in analyzing mixed variables that are not integrated in the same order is Autoregressive Distributed Lag Model (ARDL), proposed by Pesaran, Shin, and Smith $(1999,2001)$.

\section{The Monetarist Equation}

The monetarist price equation is derived from Fisher's equation popularly known as the quantity theory of money. It is presented as follows:

$M V=P Y$

where $M$ is money supply, $V$ is the velocity of money in circulation, $P$ is price level, and $Y$ is output level. Note that it was "T" which stands as a transaction that was replaced by $\mathrm{Y}$ the output level in the latest version of the equation.

By totally differentiating Equation [1] (based on Dowling, 2001) (see Appendix 1 for the working), it will become:

$$
\frac{\Delta M}{M}+\frac{\Delta V}{V}=\frac{\Delta P}{P}+\frac{\Delta Y}{Y}
$$

where $\Delta$ is the difference operator, and the rest of the variables as defined in the previous equation.

With the assumption of a constant velocity of money in circulation $\left(\frac{\Delta V}{V}=0\right)$, Equation [2] becomes: 
$\frac{\Delta M}{M}=\frac{\Delta P}{P}+\frac{\Delta Y}{Y}$

$\grave{M}=\dot{P}+\grave{Y}$

By setting: $\frac{\Delta M}{M}=\dot{\mathrm{M}}, \frac{\Delta P}{P}=\dot{\mathrm{P}}$, and $\frac{\Delta Y}{Y}=\grave{\mathrm{Y}}$

And also setting Ṕ to be the subject of the formula Equation [4] will become:

$\dot{\mathrm{P}}=\hat{\mathrm{M}}-\grave{\mathrm{Y}}$

Equation [5] is the final equation of inflation in respect of the monetarist theory of inflation. It implies that the change in price level ' $\mathrm{P}$ ' comprises the change in the quantity of money supply 'M' less (minus) level of economic (output) growth ' $\dot{Y}$ '. In summary, it also stated that an increase in money supply beyond what is required by the economy (as measured by economic growth) would end up increasing the level of prices of goods and services in the economy.

It is important to note that the monetarist inflation model/equation is specified without an intercept or autonomous variable that may affect price level independent of the money supply. This is due to the presumption that inflation is solely caused by an increase in money supply beyond what is required in the economy.

\section{The Model}

In keeping with Pesaran, Shin, and Smith (1999) and considering equation [5], the ARDL model is presented as follows:

$$
\begin{aligned}
\Delta I N F L_{t}=\beta_{0} & +\sum_{k=1}^{n} \beta_{1} \Delta I N F L_{t-k}+\sum_{k=0}^{n} \beta_{2} \Delta B R A G L_{t-k}+\sum_{k=0}^{n} \beta_{3} \Delta G D P L_{t-k}+\theta_{1} I N F L_{t-1} \\
& +\theta_{2} B R A G L_{t-1}+\theta_{3} G D P L_{t-1} \\
& +\cup_{t}
\end{aligned}
$$

INFL is the inflation rate represented by the log of Consumer Price Index (CPI), BRAGL is money supply represented by the log of broad money supply, and GDPL is a log of Gross Domestic Products as a measure of economic growth. $\beta_{i}$ and $\theta_{i}$ are parameters with expected positive signs for coefficients of money supply and negative signs for coefficients of GDP. The autonomous coefficient and the coefficients of the lag value of inflation are supposed to be totally insignificant in respect of their signs (as assumed by the monetarist theory of inflation), $\cup_{t}$ is the error term or random variable.

Equation [6] can be divided into a short run and long run equations:

$$
\begin{aligned}
& \text { Short run Equation } \\
& \qquad \Delta I N F L_{t}=\beta_{0}+\sum_{k=1}^{n} \beta_{1} \Delta I N F L_{t-k}+\sum_{k=0}^{n} \beta_{2} \Delta B R A G L_{t-k}+\sum_{k=0}^{n} \beta_{3} \Delta G D P L_{t-k}+\vartheta_{0} E C T_{t-1}+\mathrm{U}_{t}
\end{aligned}
$$

where: $\vartheta_{0}$ is the speed of adjustment and ECT is the error correction term, the rest of the variables as defined in the previous equations. 
Long run equation

[8]

$$
I N F L_{t}=\theta_{0}+\sum_{k=1}^{n} \theta_{1} I N F L_{t-k}+\sum_{k=0}^{n} \theta_{2} B R A G L_{t-k}+\sum_{k=0}^{n} \theta_{3} G D P L_{t-k}+\mathrm{U}_{t}
$$

All the variables and coefficients are as defined in the previous equations

Data

Data for all variables in this research are for Nigeria and sourced from the World Development Indicators (WDI) of the World Bank for a period of 48 years $(1970-2017)$. Annual data are used. CPI is used as a proxy for inflation, GDP as a measure of economic growth, and broad money supply represents the money supply in the economy. All the data series are transformed into a natural $\log$ form.

\section{Results}

This section presents the analysis and findings of the study. It starts with the characteristics of the variables, the unit root test, and the rest of the analysis. The characteristics of the variables and correlation analysis are presented in Table 1 and Table 2.

Table 1. Characteristics of the Variables

\begin{tabular}{lccc}
\hline & INFL & BRAGL & GDPL \\
\hline Mean & 2.658 & 26.028 & 25.135 \\
Median & 2.560 & 26.162 & 24.846 \\
Maximum & 4.288 & 30.734 & 27.066 \\
Minimum & 1.241 & 20.702 & 22.940 \\
Std. Dev. & 0.693 & 3.178 & 1.086 \\
Skewness & 0.584 & -0.005 & 0.177 \\
Kurtosis & 2.924 & 1.734 & 2.228 \\
& & & \\
Jarque-Bera & 2.739 & 3.204 & 1.444 \\
Probability & 0.254 & 0.202 & 0.486 \\
& & & \\
Sum & 127.606 & 1249.351 & 1206.497 \\
Sum Sq. Dev. & 22.570 & 474.618 & 55.462 \\
Observations & & & 48 \\
\hline
\end{tabular}

Table 2. Correlation Analysis of the Variables

\begin{tabular}{c|ccc}
\hline & INFL & BRAGL & GDPL \\
\hline INFL & 1.000 & & \\
BRAGL & ---- & & \\
& -0.085 & 1.000 & \\
GDPL & 0.565 & ---- & 1.000 \\
& -0.207 & 0.866 & ---- \\
\hline
\end{tabular}

From the correlation table, a negative link between money supply and inflation is noted, contrary to the theory's prediction. A negative link between economic growth and inflation is 
also shown, as predicted by the theory. The result of the unit root test indicates that the variables are mixed and presented in Table 3.

Table 3. Results of Unit Root test

\begin{tabular}{lllll}
\hline- & ADF & ADF & PP & PP \\
\hline Variables & Level & 1st Difference & Level & $1^{\text {st }}$ Difference \\
\hline INFL & $-3.929 * * *$ & - & $-3.707^{*}$ & - \\
& $(0.0038)$ & & $(0.071)$ & \\
BRAGL & -2.603 & $-4.049 * *$ & -1.738 & $-4.058^{* *}$ \\
& $(0.2811)$ & $(0.0137)$ & $(0.7184)$ & $(0.0134)$ \\
GDPL & -2.176 & $-5.4442^{* * *}$ & -1.534 & $-5.5027 * * *$ \\
& $(0.4911)$ & $(0.0000)$ & $(0.8033)$ & $(0.0002)$ \\
\hline
\end{tabular}

Notes: ‘*' ‘**' ‘***' represents statistically significant at 10, 5, and 1 percent level, respectively. Figures in parenthesis represent probability. ADF is Augmented Dickey-Fuller, and PP represents Philips Peron

Table 3 shows that INFL is stationary while BRAGL and GDPL become stationary after first difference in both tests (ADF and PP).

Wald and Bound Tests Results

Table 4 presents the results of the general ARDL estimation used for the Wald test and Bounds test and subsequently for estimating the short-run and long-run results.

Table 4. ARDL $(2,4,0)$ Results of the General Estimation

\begin{tabular}{lcccc}
\hline Variable & Coefficient & Std. Error & t-Statistic & Prob.* \\
\hline INFL(-1) & $0.558^{* * *}$ & 0.158 & 3.534 & 0.0012 \\
INFL(-2) & $-0.387^{* *}$ & 0.147 & -2.631 & 0.0126 \\
BRAGL & -0.852 & 0.663 & -1.285 & 0.2073 \\
BRAGL(-1) & $2.944^{* *}$ & 1.127 & 2.612 & 0.0132 \\
BRAGL(-2) & $-3.416^{* *}$ & 1.239 & -2.758 & 0.0092 \\
BRAGL(-3) & $2.264^{*}$ & 1.255 & 1.804 & 0.0798 \\
BRAGL(-4) & -0.905 & 0.698 & -1.296 & 0.2035 \\
GDPL & $-0.299^{*}$ & 0.176 & -1.697 & 0.0985 \\
C & $8.732^{* *}$ & 3.756 & 2.325 & 0.0260 \\
\hline
\end{tabular}

Notes: ' $*$ ' ‘**, ‘***' represents statistically significant at 10, 5, and 1 percent level, respectively.

Table 5. Wald Test Result

\begin{tabular}{llll}
\hline Null Hypothesis & F-statistics & Prob & Result \\
\hline All coefficients are zero & $144.7285^{* * *}$ & 0.0000 & Reject the null \\
INFL coefficients are zero & $7.027574^{* * *}$ & 0.0027 & Reject the null \\
BRAGL coefficients are zero & $2.188275^{*}$ & 0.0777 & Reject the null \\
GDPL coefficients are zero & $2.880472^{*}$ & 0.0985 & Reject the null \\
Constant is zero & $5.403949^{*}$ & 0.0201 & Reject the null \\
\hline
\end{tabular}

Notes: ' $*$ ' ‘**' ‘***' represents statistically significant at 10,5 , and 1 percent level, respectively.

The Wald test result in Table 5 shows that all the variables combined (including constant or autonomous) influence the rate of inflation. The coefficients of the previous inflation rate 
jointly influence the rate of inflation. The constant also has a significant influence on inflation. The money supply coefficients jointly have a significant effect on inflation. Also, the joint coefficients of GDP have a significant influence on inflation rate.

The bound test results confirm the existence of a long-run relationship with the value of Fstatistics 8.366483 over and above bound test's (Pesaran, Shin, \& Smith, 2001) critical value of I(0) 5.15 and I(1) 6.36 at one percent level.

The Short Run and the Long Run Results

Table 6 presents both the short-run and long-run results of the estimated model. Note that S.R is Short Run while L.R is Long Run.

Table 6. Short Run and Long Run Results

\begin{tabular}{|c|c|c|c|c|}
\hline & Coefficients & STD Errors & t-Statistics & Prob \\
\hline \multicolumn{5}{|c|}{ Short Run Coefficients } \\
\hline$\Delta \mathrm{INFL}(-1)$ & $0.387 * *$ & 0.147 & 2.631 & 0.0126 \\
\hline$\triangle \mathrm{BRAGL}$ & -0.852 & 0.663 & -1.285 & 0.2073 \\
\hline$\triangle B R A G L(-1)$ & $3.416^{* * *}$ & 1.239 & 2.758 & 0.0092 \\
\hline$\triangle B R A G L(-2)$ & $-2.264 *$ & 1.255 & -1.804 & 0.0798 \\
\hline$\triangle B R A G L(-3)$ & 0.905 & 0.698 & 1.296 & 0.2035 \\
\hline$\triangle \mathrm{GDPL}$ & $-0.299 *$ & 0.176 & -1.697 & 0.0985 \\
\hline $\mathrm{ECT}(-1)$ & $-0.829 * * *$ & 0.164 & -5.056 & 0.0000 \\
\hline \multicolumn{5}{|c|}{ Long Run Coefficients } \\
\hline BRAGL & 0.042 & 0.059 & 0.707 & 0.4839 \\
\hline GDPL & $-0.361 *$ & 0.194 & -1.862 & 0.0711 \\
\hline $\mathrm{C}$ & $10.530 * * *$ & 3.851 & 2.734 & 0.0097 \\
\hline
\end{tabular}

Table 6 presents both the long-run and short-run results. During the short run, the coefficient of the one year lag of money supply (BRAGL) is significant and inflationary. It implies that a one percent change in BRAGL leads to a change in the rates of inflation in the same direction by 3.416 percent after one year. However, the result of BRAGL, after the second year, has a disinflationary effect. Also, the coefficient of one-year lag of inflation rate is significant and inflationary during the short run. The GDPL coefficient is also significant with a disinflationary effect. The speed of adjustment towards long-run equilibrium is about 82.9 percent, which is very fast, and it is significant at one percent. During the long run, all coefficients are significant in explaining the changes in the rate of inflation except that of BRAGL.

\section{Post Estimation Diagnostic Checks}

Various tests were conducted to ensure that the model is fit. Their respective results are presented. Breusch Godfrey Serial Correlation LM test of serial correlation was conducted. The value of F-statistic is 0.100915 with a probability of 0.9043 , which signifies the absence of autocorrelation in the estimated model. Breusch Pagan-Godfrey test of heteroskedasticity is conducted. The F-statistic is 0.310672 with a probability of 0.9568 , which shows that the variance of the errors is the desired homoscedastic. The result of Jarque-Bera statistics (with a value of 1.156015) indicates that the errors are normally distributed with a probability value of 0.5610 . The Ramsey reset test for specification with F-statistic value of 0.372170 and probability value of 0.5459 implies that the estimated model is specified correctly. 
Variance inflation factor test conducted shows that the coefficients of the estimated model are not perfectly collinear as presented in Table 7, as the values of the VIF coefficient are less than ten.

Table 7. Variance Inflation Factor Test for Multicollinearity

\begin{tabular}{lc}
\hline Variables & VIF Coefficients \\
\hline INFL(-1) & 0.024937 \\
INFL(-2) & 0.021664 \\
BRAGL & 0.439361 \\
BRAGL(-1) & 1.270390 \\
BRAGL(-2) & 1.534432 \\
BRAGL(-3) & 1.574164 \\
BRAGL(-4) & 0.487609 \\
GDPL & 0.031072 \\
C & - \\
\hline
\end{tabular}

Getting satisfied results of post-estimation diagnostic checks from the estimated model makes ARDL robust to endogeneity problem apart from the inherent ability of the model to produce consistent results even with a small sample using mixed stationary variables (Jalil, Tariq, \& Bibi, 2014). The tests conducted indicate that the model is stable; the estimation is within or between the lower and upper ridgelines, as presented in Figure 2 and 3.

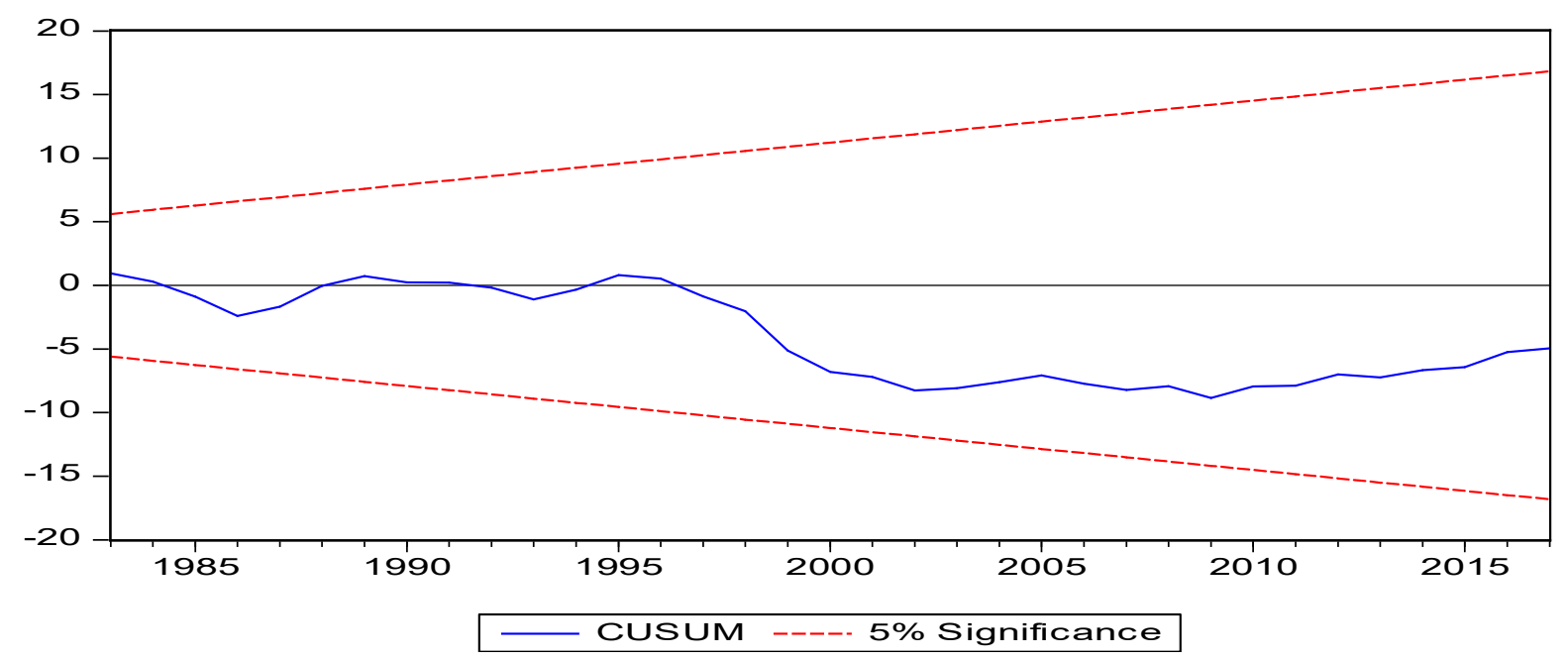

Figure 2. CUSUM-stability test 


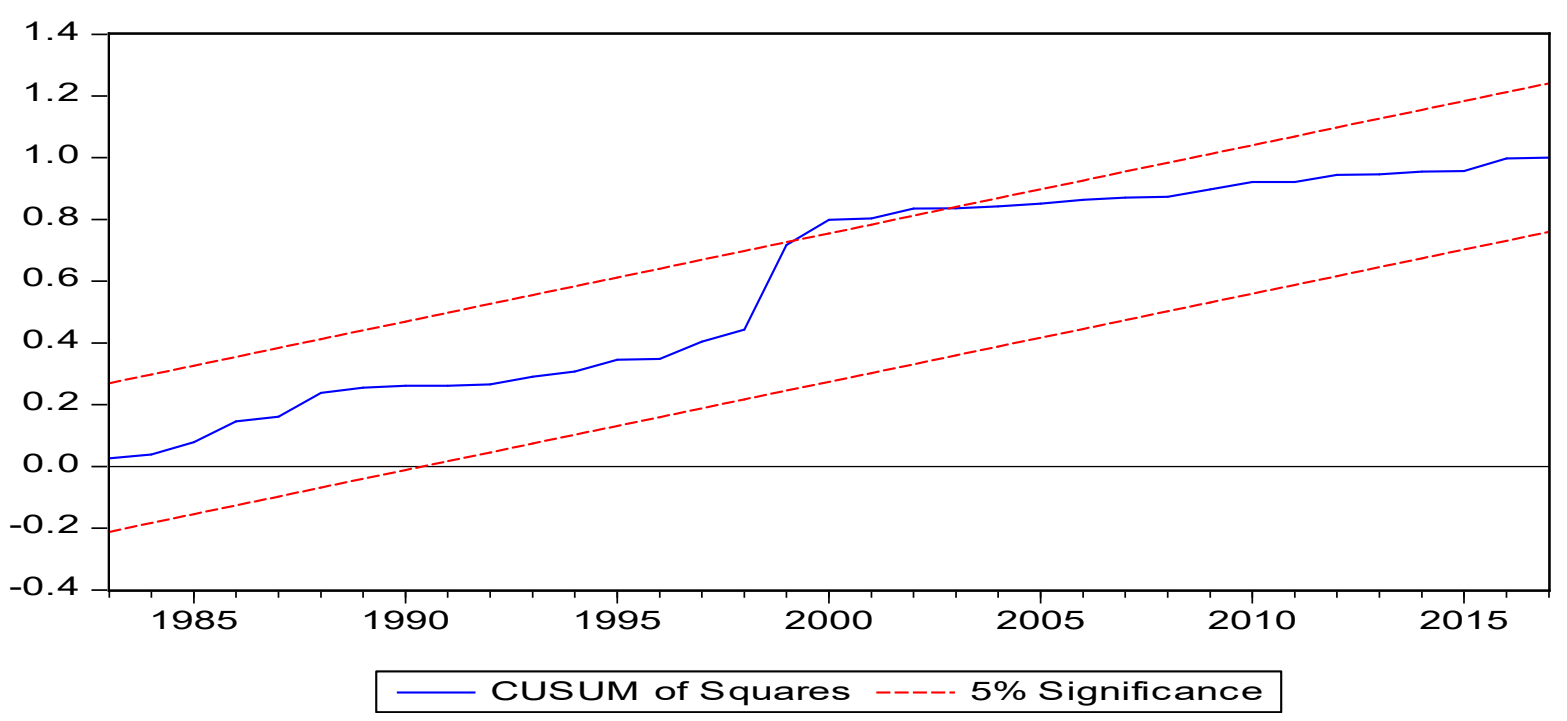

Figure 3. CUSUM of Square-stability test

\section{Conclusion}

The estimated model passed all the diagnostic checks conducted. The findings of the study indicate that in the short run and long run, the presumption of the monetarists is incompatible with the empirical results of the study. During the short run, the coefficient of the lag value of money supply (after the first year) is inflationary, as it has a positive influence on inflation rate. This is in accord with the arguments of the monetarist theory. On the other hand, lag money supply (after the second year) is disinflationary while the lag inflation rate is inflationary against the argument of the theory. The rest of the variables (current money supply and money supply after the third year) are insignificant in the short run. However, the long-run result shows that only the intercept and the GDPL are significant, which indicates that autonomous variables also influence inflation rate as against the fallacious claim that only money supply can. The $\mathrm{R}^{2}$ is around 54 percent, and the adjusted $\mathrm{R}^{2}$ is 43 percent, which shows other variables are not included that could affect the inflation rate. On that account, during the period of the study, money supply is not the sole determinant of inflation in Nigeria as maintained by the monetarists. This study recommends other theories (Keynesian, neo-Keynesian, structuralist, etc.) to be tested empirically to know which one best describes the inflation behavior in a country. 


\section{References}

Adelowokan, O. A. (2012). Exchange rate pass-through in Nigeria: A dynamic evidence. European Journal of Humanities and Social sciences. 16(1), 785 - 801.

Adu, G. \& Marbuah, G. (2011). Determinants of inflation in Ghana: An empirical investigation, South African Journal of Economics (SAJE), 79(3), 251 - 269.

Aliyu, S. U. R. \& Englama, A. (2009). Is Nigeria ready for inflation targeting? Munich Personal RePEc Archive. MPRA Paper No. 14870. available at http://mpra.ub.unimuenchen.de/14870/ Retrieved 01.12.2016

Anwar, S. \& Islam, I. (2011). Should developing countries target low, single digit inflation to promote growth and employment? International Labour Organisation, Employment Working Papers No. 87, International Labour Office, Geneva 22.

Asongu, S. A. (2013). Fighting consumer price inflation in Africa, Journal of Financial Economic Policy, 5(1), 39 - 60.

Audu, N. P. \& Amaegberi, M. (2013). Exchange rate fluctuation and inflation targeting in an open economy: Econometric approach. European Journal of Accounting Auditing and Finance Research, 1(3), $24-42$.

Bashir, F., Nawaz, H., Yasin, K., Khursheed, U., Khan, J. \& Quresh, M. J. (2011). Determinants of inflation in Pakistan: An econometric analysis using Johansen cointegration approach, Australian Journal of Business and Management Research, 1(5), 71 -82 .

Bawa, S., Abdullahi, I. S. \& Ibrahim, A. (2016). Analysis of inflation dynamics in Nigeria (1981 - 2015). CBN Journal of Applied Statistics, 7(1b), 255 - 276.

Bobai, F. D., Ubangida, S. \& Umar, Y. S. (2013). An assessment of exchange rate volatility and inflation in Nigeria. Journal of Emerging Issues in Economics, Finance and Banking (JEIEFB), 1(4), $321-340$.

Danlami, I. A. (2019). Inflation persistence in West African Commonwealth Countries. Academic Journal of Economic Studies, 5(3), 80-89.

Danlami, I. A., Hidthiir, M. H. B., \& Hassan, S. (2018). Inflation in Sierra Leone: An empirical analysis of the impact of interest rate on price level changes. Academic Journal of Economic Studies, 4(4), 42-49.

Dowling. E. T. (2001). Introduction to mathematical economics. $3^{\text {rd }}$ Edition. McGraw-Hill: New York.

Hossain, M. T. \& Islam, N. (2013). An economic analysis of the determinants of inflation in Bangladesh, The International Journal of Social Sciences, 11(1), 29 - 36.

Jalil, A., Tariq, R. \& Bibi, N. (2014). Fiscal deficit and inflation: New evidence from Pakistan using a bounds testing approach, Economic Modelling, 37(C), 120 - 126.

Jhingan, M. L. (2011). Monetary economics, $7^{\text {th }}$ Ed. Vrinda Publications (P) Ltd.: Delhi.

Lim, C. H. \& Papi, L. (1997). An econometric analysis of the determinants of inflation in Turkey, IMF Working Paper, WP/97/170, available at www.imf.org retrieved on 28/12/2016.

Lim, Y. C. \& Sek, S. K. (2015). An examination of the determinants of inflation, Journal of Economics, Business and Management, 3(7), 678 - 682.

Mawajje, J. \& Lwanga, M. M. (2016). Inflation dynamics and agricultural supply shocks in Uganda, African Journal of Economic and Management Studies, 7(4), 547 - 567.

Mordi, C. N. O., Essien, E. A., Adenuga, A. O., Omanukwe, P. N., Ononugbo, M. C., Oguntade A. A., Abeng, M. O. \& Ajao, O. A. (2007). The dynamics of inflation in Nigeria. Main Report, occasional paper No. 32. CBN Abuja, Nigeria.

Nguyen, V. B. (2014). Effects of fiscal deficit and money M2 supply on inflation: Evidence from selected economies of Asia. Journal of Economics, Finance and Administrative Science, 20 (2015), 49-53. 
Ojede, A. (2015). Is inflation in developing countries driven by low productivity or monetary growth? Economic Letters, 133(Aug 2015), 96 - 99.

Okhiria, O. \& Saliu, T. S. (2008). Exchange rate variation and inflation in Nigeria (1970 2007), Masters' Degree Project in Economics and Finance, School of Technology and Society, University of Skovede.

Omotor, D. G. (2008). Exchange rate reform and its inflationary consequences: The case of Nigeria, Ekonoski Pregled, 59(11), 688 - 716.

Pesaran, M. H., Shin, Y., \& Smith, R. J. (2001). Bounds testing approaches to the analysis of level relationships, Journal of applied econometrics, 16(3), 289-326.

Pesaran, M. H., Shin, Y., \& Smith, R. P. (1999). Pooled mean group estimation of dynamic heterogeneous panels, Journal of the American Statistical Association, 94(446), 621-634.

Phiri, A. (2012). Threshold effects and inflation persistence in South Africa, Journal of Financial Economic Policy, 4(3), 247 - 269.

Risso, W. A. \& Sanchez-Carrera E. J. (2009). Inflation and Mexican economic growth: longrun relation and threshold effects. Journal of Financial Economic Policy, 1(3), 246-263.

Sek, S. K., Teo, X. Q. \& Wong, Y. N. (2015). A comparative study on the effects of oil price changes on inflation. 4th World Conference on Business, Economics and Management, WCBEM. Proceedia Economics and Finance, 26 (2015), 630 - 636.

Shamsul-Alam, A. K. M. \& Kamath, S. J. (1986). Models and forecasts of inflation in developing economy, Journal of Economic Studies, 13(4), 3 - 29.

Simpasa, A., Gurara, D., Shimeles, A., Vencatachellum, D. \& Ncube, M. (2011). Inflation dynamics in selected East African countries: Ethiopia, Kenya, Tanzania and Uganda. African Development Bank (AfDB) Brief, 2011. 


\section{Appendix 1: Derivation of Equation (2)}

Given the following equation:

$$
M V=P Y
$$

From Equation (A.1), it can be noted that:

$$
M=\frac{P Y}{V}, \quad V=\frac{P Y}{M}, \quad Y=\frac{M V}{P} \text { and } P=\frac{M V}{Y}
$$

According to the Product Rule of Differentiation as outline by Dowling (2001), if Y=U.V, then, $\Delta Y=U . \Delta V+V . \Delta U$. Applying the product rule to Equation (A.1) we have $M . \Delta V+V \Delta M$ as differentiation for MV and $P \Delta Y+Y \Delta P$ as a differentiation for PY. Then total differentiation for Equation (A.1) is:

$$
M . \Delta V+V . \Delta M=P . \Delta Y+Y . \Delta P
$$

Recall that

$$
M=\frac{P Y}{V}, \quad V=\frac{P Y}{M}, \quad Y=\frac{M V}{P} \text { and } P=\frac{M V}{Y}
$$

Substitute the values of M, V, Y and P, appropriately into Equation (A.2):

$$
\begin{gathered}
\frac{P Y}{V} \Delta V+\frac{P Y}{M} \Delta M=\frac{M V}{Y} \Delta Y+\frac{M V}{P} \Delta P \\
\frac{P Y \Delta V}{V}+\frac{P Y \Delta M}{M}=\frac{M V \Delta Y}{Y}+\frac{M V \Delta P}{P}
\end{gathered}
$$

Factor out PY from left side of the Equation and MV from right sides

$$
P Y\left(\frac{\Delta V}{V}+\frac{\Delta M}{M}\right)=M V\left(\frac{\Delta Y}{Y}+\frac{\Delta P}{P}\right)
$$

Recall Equation (A.1), MV=PY, therefore substitute MV as PY

$$
M V\left(\frac{\Delta V}{V}+\frac{\Delta M}{M}\right)=M V\left(\frac{\Delta Y}{Y}+\frac{\Delta P}{P}\right)
$$

Divide both sides by MV

$$
\frac{M V\left(\frac{\Delta V}{V}+\frac{\Delta M}{M}\right)}{M V}=\frac{M V\left(\frac{\Delta Y}{Y}+\frac{\Delta P}{P}\right)}{M V}
$$

Hence

which is Equation (2) in the paper.

$$
\frac{\Delta V}{V}+\frac{\Delta M}{M}=\frac{\Delta Y}{Y}+\frac{\Delta P}{P}
$$

